\title{
Rethinking the Financing of Post-Compulsory Education
}

\author{
JEAN-CLAUDE EICHER and THIERRY CHEVAILLIER \\ IREDU-CNRS, Université de Bourgogne
}

Article publié dans Higher Education in Europe, vol.27, $n^{\circ} 1-2,2002$, pp.69-88

DOI : $10.1080 / 0379772022000003233$

\begin{abstract}
:
Throughout the world, the financing of education is in a state of crisis, a condition made even more acute by the simultaneous appearance of a doctrinal crisis with regard to the ends and the utility of education. For European higher education, the situation calls for the diversification of funding mechanisms. The public authorities, which up until now have borne most of the burden of higher education financing, must transfer a goodly portion of the burden to users, i.e., students and parents, and to the private sector. Various methods for financial diversification are explored as well as different formulae for user-financing.
\end{abstract}

\section{INTRODUCTION}

Throughout the world, the financing of education is in serious crisis.

The crisis of educational finance is not limited to the problem of meeting the obligations of societies to provide some minimum amount of compulsory education to their students. This minimum does not assure the preparation of an appropriately trained labour force in a world that is increasingly technological and in which a competitive economy requires the replacement of traditional production processes with ones based upon sophisticated labour and capital. The rapid growth of post-compulsory systems of education is no longer a luxury, but a necessity for industrialization and economic development. Properly trained engineers, managers, professionals, and high-level technical and administrative support personnel are crucial to the establishment of efficient industries and government services and thereby to the generation of employment for those with only compulsory schooling. This is not to say that top financial priority should be given now and in all countries to the higher levels of the school system. Basic education is still far from being universal in many Jess developed countries, especially in sub-Saharan Africa, and, in many instances its quality has been deteriorating, sometimes drastically. Where this is the case, basic education does remain a priority and its part in the education budget should, if anything, increase. But expansion and improvement of post-compulsory education (PCE) is considered to be crucial in industrialized and semi-industrialized countries and is, in the long run, a condition for the development of the poorest countries, especially if we remember than PCE takes many forms, including not only university-level education, but also, in many countries, upper secondary level education and post-secondary options, such as short course technological institutes, community colleges, as well as training programmes run by industries or trade unions.

At all levels of education, the financing of post-secondary education can be considered as being particularly problematic. The reason for this is that the funding crisis, much broader and deeper now than in the late 1960s, when it was first announced by P. Coombs, is made even more acute by a growing crisis of confidence that makes many governments less and less willing to subsidize education as generously as in the past. These crises have already led to many changes in the finance and governance of schools and especially of higher education institutions. The handful of models of institutional arrangements one could observe in the 1960s are much less clear-cut today. A tendency towards a more rnixed system of financing is 
visible. Although most innovations have been implemented some what individually as emergency measures, there are many ingenious alternatives that are worth evaluating and considering as a starting point towards more comprehensive reforms.

\section{The funding crisis}

Since the 1950s in developed countries, and a little later in most developing countries, the demand for education has increased tremendously, often explosively. Both demographic factors and rising expectations on the part of families have played important roles in the expansion of post-secondary education, especially in developing countries. Supply responded to this new situation, and enrollments experienced a spectacular growth.

In higher education, they reached levels never exhibited before Growth was of an explosive nature in most developing countries. For instance, in the thirty years between 1955 and 1986, enrollments ... multiplied by 36 in Indonesia, 33 in Thailand, 63 in Venezuela, 60 in Congo, 87 in Madagascar, 103 in Kenya, and 112 in Nigeria.

But the increase was also very rapid in most developed countries, at least until 1980. Enrollments ... multiplied by 15 in Spain between 1955 and 1986, 9.7 in Sweden, 9.4 in Austria, and 6.7 in France.

But growth has been slowing everywhere since the late 1970s, with the exception of developing countries like Indonesia, the Republic of Korea, and Thailand, which created "open universities".

This tremendous expansion implied a formidable financial effort in favour of education. At first, public budgets for education were sharply raised. The share of gross domestic product (GDP) spent publicly on education increased ... rapidly during the 1960s. On average, expenditure increased twice as fast as GDP during the first part of the decade and, although relatively a little more slowly, still more than half again as fast until 1970. Although a movement towards stabilization of the ratio was visible in the $1970 \mathrm{~s}$, it still increased in a majority of countries in every world region, until around 1980. Since then, there has been a marked reversal of the trend, so that, today, a large majority of countries, both in the developed and in the developing world, have either stabilized, or more often, have reduced their public effort in favour of education.

Beyond the general upward trend, apparently slowing down, and in many cases, reversing itself towards the end of the period, six phenomena should be pointed out.

Although developing countries seem to be spending a smaller part of their resources on education, they are "catching up" with developed countries, which means that their efforts have been more intense in the past and therefore will be more difficult to sustain in the long [run].

A tendency towards stabilizing the effort was more noticeable in the former than in the latter group, in the early 1970s (the average percentage moved only from 3.63 to 3.69 against a gain from 4.86 to 5.24, in developed countries), which may reveal that, as foreseen by Philip Coombs in 1965, the financial crisis struck many of the developing countries earlier.

The economic crisis, which hit market economies after the first "oil shock" of 1973, induced a sharp apparent increase in the public effort in favour of education in both developed and developing countries. But it is difficult to conclude that it reveals the high priority given to education at a time of dwindling resources, because a more detailed analysis shows that it is mostly the result of inertia: it is due to the low income elasticity of educational expenditures in the short run, made up as they are of wages and salaries in a larger proportion than [in] most other public budgets.

The trend reversal is more visible in the late 1970's in countries in which education was less 
strongly subsidized by the State. It is a consequence of both a greater flexibility in financing and a quicker change of attitudes towards education.

In developing countries, at all levels, and in developed countries, in most cases at the tertiary level, stabilization of effort means less spending per student as the enrollments increase more rapidly than GDP and/or public budgets.

The willingness to spend public money for post-compulsory (and even more for postsecondary education) decreased more sharply than for compulsory education.

It is clear that the reversal of the upward trend, in some cases sharp enough to lead to a reduction, not only in the effort in favour of education but also in the amount spent on education, was not caused by a lessening of the demand for education. In developed countries, it is true that the decline of fertility since the mid-1960s has led to a decrease in the number of pupils, first in primary schooling, then in the whole compulsory cycle. But in post-secondary education, this decline has been felt only recently, and demand is still increasing. Statistical studies of youth unemployment show that the probability of unemployment is negatively correlated with the level of schooling. Young people are aware of this fact and try to stay in school as long as they can.

In developing countries, with the notable exception of China, the slowdown of demographic growth is almost nowhere important enough to lead to a decrease in the absolute number of school-age children. In Africa, the demographic revolution is still in its explosive phase, and the number of potential students is still increasing in most countries by 3 percent a year. Present and expected future benefits of education, along with the low private cost involved, especially in periods of very high unemployment, [have] induced large numbers of secondary school-leavers to register at universities.

At the same time, in all countries, the pressure on public budgets [has] increased. On the one hand, the slowdown of economic activity [has] had an unfavourable influence on tax revenues; on the other hand, competing expenditures like unemployment compensation, agriculture, health, foreign debt service, and sometimes, military expenditures [have] tended to take precedence over education.

The conclusion is clear. There is a financial crisis in education in most countries. That crisis is much deeper than macrostatistics reveal; and it is not going to disappear soon, especially in developing countries, if new solutions are not found.

But the crisis has also been intensified by the fact that education is no longer considered to be a panacea. There is a doctrinal crisis as well.

\section{The doctrinal crisis}

The tremendous expansion of education in the 1960s was made possible by the fact that most governments put a great deal of public resources into that sector. They reacted so positively and so quickly because the then dominant economic theory presented education as a highly profitable investment.

By the mid-1970s, this excessive optimism and the compulsion to give first priority to education in public budgets subsided substantially when, with the rise of graduate unemployment, the capacity of educational systems to produce graduates geared to the needs of labour markets was questioned, especially in developing countries, where many accused the existing school systems of imitating the programmes of the former colonizers. The capacity and the willingness of public decision-makers to allocate resources according to social preferences was also challenged by new economic theories. All these new trends converged towards a more critical view of education and a reduced willingness to increase the public financial contribution to its development, thereby making the financial crisis more 
acute. Thus, pressed by the urgency of the situation, most countries began experimenting with or, at least, studying new ways to finance education and new types of relationships between the state and the school system, especially at the post-secondary level.

As these countries started from quite different, and sometimes opposite, institutional and financial settings, one observes a clear tendency away from extreme solutions. Countries with public financing and control are looking towards more private financing and more autonomy, at least at the higher levels of the system; countries like Japan, where private institutions, unsubsidized by the state, were dominant, have tended to introduce or to increase public subsidies and public control of the private sector.

Although most of the measures implemented in the last twenty years, especially in higher education, have been more in the nature of emergency actions than of fully thought-out reforms, economic analysis unambiguously concludes that they should be supported as long as they lead to increasingly diversified solutions to the financing of education.

But constraints are strong and manifold. History has moulded the various national school systems in different ways so that there is no unique optimal "scientific" solution to the problem of the [financing] of post-compulsory education. One must be aware that it would be a dangerous mistake to impose radical changes which failed to take into account the practical and social constraints and the political process of each given society.

Taking these constraints into account, however, it is still possible to find solutions suitable to each given situation, as long as one is clear about one's own priorities and objectives. Although each country has its own peculiarities and must find its own optimal set of rules, it is possible to make recommendations, which are broadly valid for groups of countries sharing the same problems of management and funding.

One needs however to distinguish between the problems and the solutions applicable to higher education and those of post-compulsory secondary education because, in the latter case, public financing is likely to remain dominant and public control tight. Nevertheless, the same broad set of questions needs to be answered in all cases.

\section{The main questions}

The first and the broadest of those questions are: Who should pay for education? Most innovations involving a broadening of the resource base through the contribution of a new group (or a larger contribution of an existing supporter) have been forced upon systems and/or their institutions by circumstances. There is no evidence that those moves were towards the optimum. One must therefore try to build upon what economics can tell us about the optimum financing of education. As we shall see, one broad conclusion is that mixed financing is better than either exclusively public or exclusively private financing.

This conclusion, in turn, raises a second question: Should mixed financing imply a dual system of schools, public schools being financed through public monies and private schools receiving their support solely from private sources? Our conclusion is that mixed financing is advisable for both public and private institutions. The next three questions relate more specifically to the financing of the educational services offered by schools.

Firstly, assuming that these services should be subsidized by the State, should the money be given to the institutions or to the students who attend them?

Secondly, as other sources of finance: firms, philanthropy, and, in developing countries, foreign aid, may be tapped, what should be their contribution and how should it be given and received? Choices are still more open but, at least as far as financing by firms is concerned, conclusions seem warranted: First it could and should increase in many countries; second it should be provided according to varied contractual arrangements. 
Thirdly, is it possible to use resources in a more efficient way, thereby lowering unit costs?

The last question concerns the cost of education to the student, including the cost of living while studying. Assuming that the latter should not be charged the total cost, how should he [or she] be helped? Should he [or she] receive grants, loans, or a combination of both?

\section{Who should pay for what in post-secondary education?}

Education is a process, which changes the characteristics of those who go through it, thereby enabling them to receive various satisfactions, immediately or later.

But it is also appreciated by society as a whole, which for various reasons feels that it should not be bought and sold through the market on a purely commercial basis. In other words, a case can be made in favour of both the public and the private financing of education.

\section{The Case for Public Funding of Education}

In market economies, competition among buyers and sellers and between the two groups is supposed to lead to the best possible use of available resources. But economic textbooks also teach us that several conditions have to be met in order for this optimum result to be achieved. Some of them are not fulfilled in the case of education.

First, certain goods can be used by several people in a non-competitive way, that is, entirely and simultaneously consumed by each of these people. Such goods will not be voluntarily purchased on a market if it is not technically or economically feasible to prevent anyone in particular from using them, since they are available to everyone as soon as they are produced. This difficulty, referred to as the "free-rider" problem, dissuades private firms from incurring the costs of producing them. If the goods in question are considered important by society, they will then have to be financed through non-market devices such as taxation or philanthropy and offered to all. Strictly speaking, education does not belong to that category of "pure public goods", as it is always possible to forbid a potential student to sit in a classroom. It is, however, often argued that education combines characteristics of both a public and a private good, the quality of education being indivisible, at least for a given institution. When more and more students are crowded in the same room, quality decreases, not only for the newcomers but also for those who [have] already [been] there. This situation creates a case for public funding to produce or to maintain quality in education. The students and their families have no way to accurately evaluate the quality of teaching. Private suppliers could therefore be tempted to increase the quantity, i.e., the number of seats they offer, even though this has an adverse effect on quality.

Information available to the students is also imperfect in another way. The ultimate outcome of education is spread over time and could be affected by many events, most of which cannot be foreseen. The argument is often made that this uncertainty leads many young people to underestimate the true future benefits of education and therefore to under invest in it, if they have to pay the full costs of their studies. Along the same lines, one can state that uncertainty about the future earnings of graduates make lenders unwilling to finance education at going market rates. This unwillingness increases the costs of education for those who cannot finance it with their own resources and further reduces the demand for it.

Another point in favour of the public financing of education is the existence of what economists call positive externalities. Most goods give satisfaction or other advantages only to those who acquire them. Some entail benefits to other groups or to society at large, over the sum of individual benefits, which they bestow on their owners. These extra social benefits are attributed to external effects or externalities. 
Education is supposed to produce positive externalities of both an economic and a noneconomic nature. They range from the contribution of advances in knowledge to economic growth and increases in the flexibility of labour markets to the transmission of literacy, aesthetic and cultural values, and more efficient political participation. This wide consensus has led to the generally accepted conclusion that these positive externalities justify substantial government intervention.

Finally, public financing may be justified from quite a different point of view, that of the State (public authorities). If one considers government not as the representative of the whole community but as an institution trying to maximize its revenue, the influence of education on the ability of graduates to pay taxes out of the extra income they will earn has to be taken into account. If the government reckons that it will get more out of the future incomes and outlays of graduates than it is currently spending in order to expand or improve education, it is justified in maintaining a budget for education.

But one should note that if all the arguments examined above are in favour of some public contribution to the funding of education, they do not lead us to conclude that it should cover the whole cost.

\section{The Case for the Private Financing of Education}

The main reason why individuals (or their families) should pay for the education they receive, at least beyond the compulsory level, is well known. They acquire private benefits through higher income and social status, greater efficiency in consumption, better health, increased political efficacy, and greater access to and better understanding of culture, science, and technology.

Other arguments in favour of the payment of fees by students can be found on the supply side. First, there is the well-known "token user charge" argument. People are inclined not to appreciate what they do not have to pay for and consume free goods indiscriminately and wastefully. When a fee, however modest, is collected, rationality tends to increase.

Second, when the customer pays for what he gets, he is entitled to pass judgment over the product. When schools charge fees, they have to take into account student preferences and organize their curricula accordingly. The resulting situation promotes the "internal efficiency" of educational institutions.

Third, fees represent extra revenue for publicly funded institutions, thereby enabling them to maintain quality in times of budgetary squeeze.

But private enterprises also gain benefits from education. General education reduces the need for training and the costs of retraining when shifting to new products and technologies, while specific training and research programmes may increase productivity. There is no obvious reason why consumers should not pay for what will benefit them.

Finally, if philanthropists get satisfaction from the development of education, one can expect them to provide funds in support of it.

The above arguments show quite clearly that one can make a convincing case in favour of both the public and the private financing of education. The optimal solution appears to be a mixed system. But this [conclusion] leaves untouched a very important question: What should be the portion of each participant?

On principle, the answer is simple. Each entity or constituency should pay for education according to the benefits it receives. But many of those benefits are difficult or impossible to measure. No individual student knows with a reasonable certainty what he will earn throughout his active life; neither is he able to quantify the non-monetary benefits he expects from going to school beyond the compulsory period. Firms tend to discount the advantages they get from graduates. Philanthropists have to choose among various competing uses for 
their money. They are interested in the cost-effectiveness of the funds they intend to donate but have no objective criteria to guide them in their choices.

All things considered, the choice of the precise mix depends more on the practical and social constraints of a given society and on the political process than on the rational views of researchers and evaluators. But this does not mean that nothing can be said about the consequences of a given choice.

\section{Private versus public education}

Different countries make widely different choices about the public-private division of responsibility for PCE, especially at the higher education level. On the other hand, there are good reasons to recommend both its public and private financing. Does that mean that the optimal solution is a dual system comprising public institutions fully supported through public apportionment and of private institutions charging full cost covering fees? Empirical observations show that this extreme solution is very seldom adopted. Logic militates [for] ...more mixed solutions.

There are several arguments in favour of public subsidies to private schools: Subsidies maybe necessary for a large expansion of a private sector in education. The costs of PCE and still more of higher education are high. Few students (or their families) are able to pay them in full. Private institutions can only hope to attract large numbers of students if they charge below cost fees. Subsidies may generate savings to the public budgets if they divert more students from public schools than would unsubsidize private schools.

They may at the same time help to meet cultural and economic aims and to ensure political stability if they allow rninorities to attend schools of their choice at a reasonable cost.

They may help shift part of the financial burden to the households, when law or tradition prevents or makes very difficult the levying of fees by public institutions.

They may allow the state to impose controls on private schools in return for the subsidy, thereby making sure they do not peddle subversive ideas or, more generally, that they offer education of at least minimal quality.

There are also strong arguments in favour of some private financing of public institutions: The token user charge argument quoted above.

The rate of return argument: Why should students receive their education free when they will earn more after graduation?

The autonomy argument to be developed later on.

Conclusion: The distinction between public and private education is not always as clear-cut as it seems. Private management does not always mean purely private financing. Allowing a publicly subsidized private sector to expand can alleviate budgetary strains. Encouraging public institutions to seek other (private) sources of income will reach the same goal.

\section{Public financing of education: subsidies to institutions or to students}

Even if a broad agreement exists that post-compulsory education should be subsidized by the State, institutional ways by which those subsidies are channeled differ widely from country to country (and from state to state, in federal countries).

Those arrangements do have differential effects on the working of systems which have to be clearly understood in order to guide public choices.

Broadly speaking, there are two "pure" (polar) solutions. Either the support is offered to the 
institutions or it is given to the students. In the latter (pure) case, the institution charges a fee covering the full cost of the services it offers, and the student gets a grant or a subsidized loan from the State. In the former case, the institution determines the range and the quality of its services according to the State subsidy and the linear resources it is able to gather (student fees, grants from firms, etc.).

\section{Institutional Support}

Student support can take two forms: general and specific. In the first case, public funds are used to support the general educational functions of the institutions in the form of annual budgets calculated on the basis of a more or less complicated funding formula and provided through the normal budgetary allocations by the appropriate governmental units. In contrast, specific grants represent those that are given to institutions for specified purposes.

Traditionally, public money was given to institutions mainly in the form of specific or restricted grants. Staff wages and salaries were paid either directly by the state or, on a national scale, by each institution from a state grant. This type of institutional arrangement tended not to induce innovation but rather to bind the hands of the payer as well as those of the payee.

Apparently, unrestricted block grants, when they existed, were generally so low that they did not offer choice to institutions. An exception was the case of the United Kingdom where, for a long time, the generous unrestricted grants which were used to finance universities left them a great deal of freedom. But it is generally considered that this arrangement did not promote more innovation and competition than did the restricted grants that were allocated to the other higher education institutions of the country, the Polytechnics and the Colleges.

Neither solution leads to optimal results. Unrestricted block grants do not provide incentives and tend to shrink through time. Specific grants do not ensure the long-term stability, which institutions need and may be given more in accordance with passing priorities and fancies of elected bodies than with a thought-out pattern of development. The stimulus that is needed to urge the institutions to innovate could be provided by a combination of a basic allocation with a formula linked to objective criteria like the number of students and specific grants towards development programmes agreed upon jointly by the institution and the funding body on a contractual basis and subject to evaluation. Such procedures are being tested or implemented in a few European countries and seem to be giving good results.

This combination may also increase total funding in two ways: first, by resulting in larger grants to innovative institutions; second, by matching the specific grants with additional resources obtained from other public or private sources.

One condition that has to be fulfilled for these new procedures to yield the expected positive results is that leeway be given to institutions in their use of public money.

\section{Student Support}

Student-oriented support can take the form of grants (such as scholarships or maintenance grants) or loans. Obviously, if the public authorities were to substitute student-oriented approaches for institutionally oriented ones, the budgetary subsidies to institutions would decline forcing the latter to raise student fees. Students would pay higher tuition fees with the funds that they would receive from the State. State institutions would still receive State support indirectly through the public funds provided to students for their education as well as any direct institutional funding retained.

This solution is supposed to increase the range of choice of students, especially if private institutions are eligible to participate. It may also promote equity as the amount of the subsidy 
can be tailored to student economic circumstances and backgrounds. It creates competition for students among institutions. But such competition is not necessarily a good thing as it will not only increase diversity and in some sense productivity but also probably favour short-term strategy at the expense of long-range planning, and sometimes encourage "fadism" and poor quality alternatives in order to attract students. Furthermore, it will probably induce a reduction of the programmes, the benefits of which accrue to the larger society rather than to individual students.

Considering the mixed results of each "pure" solution, it seems reasonable to recommend a combination of institutional and student support. To be more specific, as long as postsecondary educational institutions provide social benefits to the State that are external to those received by students and their families, there is a rationale for some institutional support. Benefits, which depend on student choices and participation, should be funded through student support. But, on the whole, one thing is clear: There is a strong case in favour of shifting to more student oriented subsidies in many countries, especially in Europe, where public support is overwhelmingly given to institutions.

Such a shift would open the question of the type of support to he provided to students (grants or loans) and of how it should be administered.

\section{Other sources of finance}

Educational institutions do not have to rely exclusively on public subsidies and/or on student fees. A general conviction exists that business at large has a legitimate interest in PCE, which makes a case for firms to bear a part of its cost. But the institutions, especially the universities, may also derive income from their own assets. Philanthropists may be induced to provide additional resources. Lastly, international assistance should sometimes be solicited in developing countries.

\section{Financing by Business}

Firms do contribute to the public subsidization of institutions or students through general taxation. But specific ways can also exist by which they can be induced or forced to share the burden, like taxes earmarked for education and levied on turnover or on payroll, or through tax exemption for gifts. An interesting example is the French taxe d'apprentisage, a payroll tax ( 5 percent) that is waived if firms make a donation of the same amount to freely chosen institutions of vocational and technical education, either directly or through business associations.

Firms sometimes need neither incentives nor compulsion to contribute to the financing of education when they find a way of solving their own problems by contracting with educational institutions for specific services.

In a rapidly changing technological environment, firms need to provide their workforces with more training than in the past. On-the-job training is still important, especially, in order to adapt newly hired workers to their jobs. But the teaching of new skills is even more important, as is the adaptation of the workforce to new processes and to a new organization of labour.

Firms are not able to perform all of these tasks by themselves; they have to contract with training institutions. Technical schools and universities can provide part of this training, but most of the courses they offer are not adapted to this new demand. They have to set up continuing education departments, financed by fees paid by firms for their trainees. However, their teaching staffs [may] be reluctant to enter these new and often more exacting activities 
unless they are permitted to receive financial rewards on top of their statutory salaries. As far as the institutions as such are concerned, they have an incentive to develop such departments only if part of the extra resources are likely to spill over to traditional teaching and research or if this type of work leads to the development of links with business, thereby facilitating infirm placement and eventually jobs for their students.

As a matter of fact, firms can also contribute to education by providing opportunities for students to bridge the gap between the abstract knowledge acquired in education and operational skills when they offer them practical work experience during their periods of study.

These contributions are real. They must not, however, be seen as a diversification of the financial resources of higher education institutions but rather as a consequence of a diversification of their purposes and activities.

\section{Research Services for Business}

"Pure" research is conducted either jointly with education and financed through education or independently with specific funding by the state or by philanthropists. Applied research bridges the gap between "pure" research and the production of goods and services. It is directly linked to production processes and can be considered as a specific type of productive investment by firms and public organizations. Because training and applied research are closely linked, firms and education institutions can enter into mutually fruitful co-operation agreements that will only be efficient as long as they remain specific and limited in scope.

Applied research could generate extra resources if universities were to exploit their intellectual property rights by patenting or licensing to industry inventions made in their laboratories thus participating in the so-called transfer of technology. Although this type of arrangement is very promising, it is a difficult path upon which to embark. On the one band, the tradition of academic research, which includes the free dissemination of new knowledge, is hardly consistent with the secrecy needed when developing a new product in a competitive environment. Publication of results is often considered as the essential outcome of scientific activity. On the other band, many universities are insufficiently professional in protecting and marketing their ideas. But inventions hatched in university laboratories cannot go on making the fortune of private firms. Despite the difficulties, higher education institutions should strive to turn their intellectual property rights into an additional source of finance.

\section{Income from Property, Industrial, or Financial Assets}

The endowment of schools and universities with land or property has long been a simple way of securing the financial independence of these institutions, but it can no longer be considered as the main funding method for ail PCE institutions, for they would have to own too large a share of the land, buildings, and businesses of the country to be able to accumulate sufficient resources to cover most of their current expenditures.

Some donors, however, prefer to make endowments for specific purposes (like endowed chairs), and universities, even when they would rather spend the proceeds of donations immediately, are sometimes required to build up and to manage endowment funds.

In the second half of the Twentieth century, endowments have been increasingly turned into financial assets that have a higher yield than property, but are more risky. Managing these assets requires costly expertise and may create problems for institutions which were designed for a different purpose. Owing to the peculiar way they are governed, academic institutions may be tempted to exert pressure on enterprises in which they own stock to redirect their activities towards nobler or higher goals (for example, the campaigns against military 
research, nuclear industry, pollution, and apartheid in South Africa). They may also indulge in speculative or "creative" finance by using practices designed to increase revenue through taxsubsidy financing or legal devices that permit participation in equity growth from commercial enterprises (by creating subsidiaries or foundations for the sole purpose of benefiting from business tax provisions). Setting up a foundation would allow institutions to benefit from endowments without having to meddle in matters so distant from their basic purposes.

However, universities should not hesitate to create or to help in creating various enterprises whenever they are related to their teaching or research activities. These might include consultancy firms, run either by staff or students, science parks, incubators, and joint ventures for developing university-produced inventions, service agencies for exploiting their unused facilities by organizing conferences, etc.

\section{Philanthropists, Benefactors, and Sponsors}

Individual and business philanthropy flourishes in a specific environment created by a favourable tax system and a national tradition of solidarity in the local community, as opposed to reliance on a central State. Without these, even the best-organized fundraising campaigns will not succeed in providing a sustained flow of resources to PCE institutions. Provided they meet certain conditions of financial soundness and accountability, post-compulsory education institutions should be treated as tax-exempt foundations and charities and be allowed to receive tax deductible donations from firms as well as from individuals. Each institution would then be able to appeal to one or to several constituencies (alumni, business sponsors, etc ...) according to the type of project it intends to finance from the proceeds of such donations.

\section{International Assistance}

The financial situation of some developing countries is such that, in the short and middle run, they will most probably not be able to maintain a minimum level of quality and accommodate demographic expansion without outside help. But in the past, international assistance has not always been an unmitigated bonus.

TABLE 1. Evaluation of the different methods for funding educational costs

\begin{tabular}{|c|c|c|c|c|}
\hline Method & Efficiency & Equity & $\begin{array}{c}\text { Resource } \\
\text { broadening }\end{array}$ & $\begin{array}{l}\text { Administrative } \\
\text { costs }\end{array}$ \\
\hline Specific grants to institutions & + & $=$ & $=$ or + & $\bullet$ \\
\hline Vouchers to students & + & $=$ & + & $\bullet$ \\
\hline \multicolumn{5}{|l|}{ Tuition fees: } \\
\hline Token fees & + & $=$ & + & - \\
\hline Substantial uniform fees & + & - & ++ & - \\
\hline Substantial variable fees & ++ & $\bullet$ & ++ & $\bullet$ \\
\hline Full cost fees & ++ & $\bullet$ & ++ & $\bullet$ \\
\hline \multicolumn{5}{|l|}{ Financing by business } \\
\hline Contribution to the teaching & + & $=$ or $\bullet$ & + & - \\
\hline Research services & + & $=$ & + & $\bullet$ \\
\hline Educational payroll tax & + & $=$ or $\bullet$ & ++ & $\bullet$ \\
\hline Endowments and gifts & + & $?$ & + & $\bullet$ \\
\hline
\end{tabular}

These by now well-known facts lead to the following conclusion: International assistance should grow, at least for some developing countries; but it should also be reorganized. Fewer loaned teachers, fewer "gifts", but more assistance to local programmes, more subsidies to 
help cover the recurring expenses of key institutions (textbook printing presses for instance).

\section{Effects of Financial Innovations}

Everything considered, the diversification of the sources of funding of PCE institutions is a distinct possibility, but it would not be without consequences on their organization. Diversification generally strengthens their autonomy, but it also supposes a stronger management, for it increases the difficulty of achieving the consensus.

But it should be emphasized that changing the source of funds also strongly affects the working of the system as a whole or that of each member institution. The effects of various innovations introduced in a given system can be assessed according to four criteria.

Efficiency and equity, the two traditional criteria of welfare economics. Resource broadening potential, that is the capacity to generate new resources by bringing in new categories of fund providers or by inducing existing contributors to increase their funding. But new modes of financing may entail administrative costs, which may lower the net intake. If we consider, for instance, a system financed mainly through public unrestricted grants to institutions, the average effects of the main financial innovations can be summarized in Table 1. In some cases, the outcome cannot be foreseen without knowing more details about the way changes are implemented.

No single source scores high according to each one of the four criteria. The same conclusion would be reached if one started from a different initial arrangement. Two conclusions can be drawn. First, the final choice depends on the weight the final decision-maker gives to each criterion; second, a combination of different sources is in most cases to be preferred to a single source of income.

\section{Cutting costs or shifting to new operating methods}

The problem for schools and universities, in a crisis situation, is to manage to increase or, at least, to maintain their outputs. Looking for new resources is not the only solution. Finding ways to use existing resources in more efficient ways should also be recommended. Two types of changes in financial arrangements may lead to increases in efficiency (or at least in effectiveness).

First, a tightening of public subsidies: if the amount of the public grant (and/or the number of posts) decreases sharply, institutions are strongly induced to curtail all expenditures which are not essential to the day to day working of the institution, and if they are allowed to do so, to reallocate staff members. But there is generally no close correlation between the anticipated effects of restrictive financial policies and their effective consequences.

Evaluations of the consequences of policies of retrenchment in various European countries show that the effects of government policies were linked with the extent of the consultation between the ministry of education and the institutions and with the degree of autonomy of the later.

Roughly speaking, one can observe that the results were more in harmony with expectations in countries in which the universities benefited from a real degree of autonomy and were closely associated in devising reallocation plans (case of the Netherlands) than in countries in which the rules were set up by ministries or central agencies without consultation (case of the United Kingdom) and still more than in those countries in which the universities had very little autonomy and therefore where shortages of resources were often induced by the many structural rigidities of the system (case of France).

Also, one must be aware of the fact that the increase in the efficiency of teaching and research 
cannot, in most cases, be documented, for, in most instances, no reliable performance indicators have been developed.

Second, cost effectiveness can also be increased through changes in the way educational services are delivered. Traditional education is organized in such a way that its unit costs have a tendency to rise through time as its main input is highly qualified labour, the relative price of which increases. But economic history has shown that it is possible to lower unit costs by substituting capital for labour. For a long time, technological innovations were of little use in education, owing to the characteristics of its "product". But, with the communication revolutions, things are bound to change. What is generally considered to be the main objective of education, i.e., the transmission of knowledge, should be strongly affected by the availability of new media of communication, which should also help research, another main objective of education.

The first generation of those communication technologies, radio, television, and more generally, all types of audio-visual aids were the objects of great expectations. The disappointment with the results was at least as strong. On the whole, these instruments were shown by evaluators to be costly, under-utilized, and often with no significant effect on learning. But most of these evaluations concerned projects developed within the system of compulsory education and taking place inside schools.

The balance sheet is much more positive when one looks only at post-secondary education and at distance teaching. Evaluations made in developed countries in the late 1970's gave quite a sizeable advantage to open institutions. For instance, Everyman's University of Israel costs only 60 percent of what regular universities in the country did, and the cost per student in the British Open University was estimated to be only 70 percent of that in a comparable British University, at a time when the former had only 34,000 students, that is at a time when it had not yet reaped the full economies of scale connected with distance teaching.

Part of the difference is, of course, due to the fact than a much higher proportion of distance education students enroll in fields like the humanities or law, in which the cost per student is relatively low, but the fact remains that the cost is greatly reduced in every field. The second generation of new communication technologies (microcomputers, video disks, cable TV, etc.) has a much greater potential and will progressively transform higher education.

Potentially, the New Technologies of Information and Communication (NTIC) have three direct or indirect effects on the financing of post-compulsory education.

First, they enable students to receive high quality teaching without leaving their places of residence. The best specialists in each field can be used to elaborate the courseware, so that each student can follow, so to speak, the lectures of the best teachers. Furthermore, each student can choose to study according to his own schedule, at night or during weekends, for instance.

Second, NTIC may contribute to lowering the cost of education. By allowing the students to choose their schedules and study loads, they reduce or suppress foregone earnings for adults who can thereby study without giving up their regular occupations. On the other hand, if each recorded course is used by a large number of students, teacher costs per student will be very low compared to those of traditional education in which there is a teacher in each classroom or, at best, one for a small number of classrooms. Of course, the gain will be more important in school programmes in which the same curriculum is followed by many students than in adult education in which demand is much more diversified and in higher education in which the students are much more autonomous than in secondary education in which frequent contacts between teacher and students are still needed .

One should also remember that extra costs are added, those of hardware, courseware, transmission, etc. But these tend to go down over time.

Third, distance teaching using the NTIC's may be an opportunity to shift the financial burden 
of education, at least partly, to the students. They will have to buy the hardware (microcomputers, peripherals, interfaces, etc.). They may be more willing to pay for the courses themselves, that is to buy the courseware, for three reasons. If they are adults already engaged in professional activities, the fact that they forego little or no earnings allows them to enjoy a higher disposable income. If they anticipate a rise in income once they have obtained the degree or certification they seek, their willingness to pay for their studies is still greater. They may, in some cases, receive financial help from their employers who may be prepared to buy the courseware. If they are not yet actively employed, they may feel that this is the only opportunity they have of studying further, if they do not have sufficient academic credentials to be admitted to regular courses or if they are not willing or able to move to the places where courses of value to them are offered.

The new technologies may therefore, for all the reasons mentioned above, be a way to lower the cost of PCE and/or to shift part of the financial burden to the students in countries where there are no fees or very low ones.

Two caveats are yet in order. First, evaluations show that there is still a big gap between their potential and their practical effectiveness so that one may expect their spreading to be slower than anticipated by some. Second, these instruments are sophisticated, some of them highly so, and they may only function in an adequate environment. The hardware needs to be protected against extremes of weather and power surges and bas to be maintained and repaired. If minimal environmental conditions can usually be met in developed countries, such is not always the case in developing countries, especially in rural areas.

One may confidently forecast a strong development of distance higher education, to the extent that, twenty years hence, a majority of teaching will no longer be residential in most universities. These institutions will be able to obtain an important part of their resources by charging higher prices for the courseware than for regular curricula. In the developing world, one can forecast the same evolution in semi-industrialized countries, as can be seen in Asia. But these changes will come more slowly in the less developed countries, especially in Africa, where distance teaching should preferably make use of the communication technology of the first generation rather than of the NTIC' s.

Everywhere, however, the need to extend some public support to the students themselves will remain.

\section{Student aid}

Students may contribute to the financing of their own studies, especially at the undergraduate level, from their own incomes from vacation and campus jobs. The latter should be provided and subsidized by institutions and government agencies responsible for student aid on the model of what exists in the USA and should be made easier by the development of part-time study.

The burden on the students and their families may also be spread over time through various education finance schemes.

But students (or their farnilies) should not be expected to finance the full costs of going to school. This statement leaves us with three fondamental problems:

First, should only the price of the educational services offered by the school system (the cost of schooling) be subsidized or should the total cost of getting an education, including the cost of living while studying, be supported by the State (or other sources)?

Second, should students be helped through grants or through loans or some combination of both?

Third, should the aid be manipulated in order to channel candidates towards certain subjects? 


\section{Cost of Living, Cost of Educational Services}

There are reasons for not completely separating the problem of the subsidization of the cost of educational services and that of the cost of living of the student: As students have to renounce gainful employment (at least full time) in order to go to school, they cannot earn their keep. As long as university students who are above the legal adult age are officially classified as dependents, their families should normally not be expected to provide for their needs. But, one should not lump the two questions together. The reasons for subsidizing education are not exactly the same as those in favour of helping students caver their living expenses.

\section{Grants or Loans?}

Should students be helped through grants or through loans? The aim of both types of support is dual. From the standpoint of social efficiency, aid is to maximize the enrollment of able students in order to maximize human capital formation. From the standpoint of equity, aid is intended to facilitate the enrollment of every able student, whatever his or her economic circumstances. The case for each type of aid should therefore be made keeping these two aims in mind.

\section{Grants}

The precise effects of grants also depend upon the way they are distributed and managed and upon their aims: covering all or part of the schooling cost (fee subsidies) or subsidizing the cost of living (maintenance grants).

Fee subsidies are necessary as long as there is a shortage of skilled manpower, as few students (and/or their families) are able to pay the full costs of tuition fees. Such grants can be paid to students or they can take the form of vouchers. An educational voucher is a coupon of prescribed purchasing power, which can be cashed at any educational institution. The issuance of such coupons is supposed to achieve two objectives simultaneously: enforcement of the right to education for all and freedom of choice. This goal could be achieved with a much lower administrative cost, by subsidizing institutions according to the number of students enrolled in order for them to charge no fee or very low uniform fees provided that students can freely choose among institutions.

Maintenance grants can be given either in kind (subsidized accommodations, food, and transport) or in cash. In the former case, it is obvious that they can only be given to the institutions that offer those services. In the latter case, it is better that they be given to the students rather than to their parents, as it is difficult to make sure that the parents will actually spend the whole amount to cover the living costs of their children. Uniform grants clearly increase participation rates, but they can be considered as inequitable as they help the rich as much as the poor. They may even amount to a regressive distribution of income, if the tax structure is not very progressive and if participation rates are much higher for the children of well-to-do families. Furthermore, they are less efficient in boosting participation rates than income-related subsidies.

Criteria-bound grants may be of two kinds. Income-related grants are clearly meant to increase equality of opportunity. They are to be chosen if the main criterion one favours is equity. Ability-bound subsidies are given according to academic performance. They increase efficiency in that they maximize human capital formation, but their effect on equity is probably nil and may be negative.

It is still considered important to promote equity in education; even though few people still believe that educational expansion fosters a more equal income distribution. Equality of opportunity in education means that all students with a minimal level of competence should 
be able to participate beyond the compulsory level regardless of their other characteristics. Need-based student financial aid is meant to remove at least the financial barrier, often considered as the most potent one.

Student aid has clearly increased the rate of participation of poor students in higher education, allowed more of them to attend relatively costly and prestigious institutions, and to stay in school longer. But it is also clear that it has not succeeded in wiping out the effects of social environment. Its effectiveness in promoting equity is linked with the way in which it is offered, a reality, which must be kept in mind when considering student loans.

\section{Loans}

The most striking and extensive recent changes in the pattern of financial sources for postsecondary education have involved private sources: In most countries in which there was a tradition of free post-compulsory education, users, i.e., students and their families, have been increasingly asked to contribute to the costs of education.

First, support towards the cost of living has gradually shifted from the State to the students: aid-in-kind, through provision or subsidization of food, lodging, transportation, and welfare, did not follow the pace of enrollments, leaving the students to foot a larger share of the costs of these services. In many countries, these services are largely self-financing, students-in-need being increasingly supported directly through grants or subsidized loans.

Second, some of the educational costs of PCE have been transferred to the students by resorting to specific fees for additional equipment or services (laboratory, computer, library fees), which, being easily identifiable, were more acceptable to the students and their families. In a number of countries (Belgium, Spain, Netherlands, and Switzerland), general tuition fees have been increased to levels which are not nominal (ranging from $\$ 200$ to $\$ 800$ US dollars). The ever increasing costs of PCE could not be met by families out of their income or by the State out of its budget, so there appeared a need for another major source of funds which was found in the development of student loans which were increasingly advocated for the following reasons:

Since education is a profitable investment for most students even in countries where a high proportion of each age class goes beyond compulsory education, there is no reason why society should bear its total cost. If graduates earn more than non-graduates, they should be able to devote part of their extra income to repay loans.

Furthermore, students who borrow to pay for their studies are more inclined to choose their fields of study wisely and to try to go through the curriculum as rapidly as possible, in order to minimize the amount they have to borrow. Contrary to income contingent grants, which leave students from well-to-do families dependent upon the goodwill of their parents, loans enable all students to make their own choices according to their capacities and their own preferences.

Broadly, three main types of loans should be distinguished:

- Commercial Loans. These are organized like mortgages or ordinary bank loans. Their interest rates are those of the market. Repayment periods are fixed.

Such a method has several drawbacks:

As a way to finance education, it is more risky for both borrowers and lenders than are most other types of loans. Not only does a student who borrows not know, with any degree of accuracy, what will be the eventual return on his degree since it depends upon future labour market conditions and other unpredictable factors, but he is not even certain that he will graduate. Contrary to those who borrow to buy a house, he [or she] cannot offer collateral. The result is that banks are very reluctant to offer such loans without a government guarantee, and hence tend to charge high interest rates. For the same reasons, they will tend to offer only relatively short-term loans, a situation, which raises the amount to be repaid at each period. 
- Public Student Loans Programmes. Public involvement in student loans can take the form of public subsidies, permitting lenders to offer lower interest rates and deferred repayment (grace periods). But it can also consist of guarantees against default.

Owing to the great uncertainty about the future, commercial lenders tend to charge a premium to protect themselves from default on the part of a fraction of the borrowers who, having wrongly anticipated their future incarnes, will be unable to pay back their loans. This situation makes the cost of studies much higher for those who have to borrow than for those who obtain resources from their families. A public guarantee or a subsidy high enough to eliminate this cost difference would, so to speak, recreate a "perfect market" situation and correct the distortion in resource allocation. Such a guarantee or such a subsidy obviously creates a burden on the public budget, but it is likely to be a lighter one than outright grants.

But loans are frequently much more subsidized than what is necessary to correct market imperfections. These large subsidies are justified by arguments of efficiency and of equity. If there are positive externalities, that is, if education has positive effects on society at large, over and above the benefits, which it confers to each one of the graduates, students should not be made to pay the full cost of tuition. To offer them subsidized loans would be a way to shift part of the cost of tuition. But if teaching institutions are already subsidized by the State in order for them to charge lower tuition fees, subsidizing the loans above what is needed to correct market imperfection would amount to subsidizing twice the same goods which seems to complicate the administration of the system, without producing any net effect on efficiency. On the side of equity, a high subsidy can be justified only if it is limited to less affluent students. In addition to the fact that it is difficult in most countries to measure the true ability to pay, it seems more logical to try to reach the same goal through a third type of loan: one with income-related repayment.

In any case, subsidized loans have obvious drawbacks: To begin with, as they represent recurrent costs for the public budget, they tend to be rationed in periods of growing financial constraints, thus limiting access to education, as shown recently by the heavily subsidized German scheme (BA FoG). Secondly, they do not help salve the problem of the so-called "negative dowries", i.e., the transfer to spouses of the repayment of loans contracted by nonworking married graduates. This latter problem disappears with the third type of loan.

- Loans with Income-Related Repayments. Uncertainty about the return on educational investment may deter prospective students from going on studying even when the investment would turn out to be profitable. This uncertainty leads to inefficient decisions and therefore to misallocation of [some] resources. This situation can be prevented by the setting up some sort of insurance against the risk for an individual's not reaching a level of income that makes his [or her] investment in education profitable. Insurance of this sort can be achieved by a loan scheme according to which repayment is related to the actual incarne of the borrower.

There are two possible sorts of relationship between repayment and incarne:

First, repayment could be increased or reduced according to the level reached by income. This procedure provides each individual borrower with an insurance against the risk of income fluctuations. If his [or her] income goes down [owing] to unfortunate and unforeseen circumstances, he [or she] will automatically see repayment installrnents go down. It also makes the wealthy pay back more than the poor and possibly much more than they borrowed. There are two drawbacks to such loans with income-related repayment, well known to insurance specialists. The first one is called "moral hazard" and involves the conscious or unconscious behaviour of insured individuals to increase the occurrence of the events against which they are insured, to the extent that they have control of them. If more students having borrowed under such a scheme drop out or choose to live on small incarnes, the scheme will 
incur losses that will have to be borne by the public purse.

The other drawback is referred to as "adverse selection". If it is possible to "opt out" of a loan scheme with income related repayment, those students who have higher income expectations will choose to finance their education by borrowing from banks or with the help of their families, and the source for potential excess repayments will dry out. Only those who expect to do less well will borrow under the scheme, which is bound to create another source of imbalance that would have to be made up by budgetary appropriations.

Second, the loan could be repaid more or less rapidly according to the income level of the borrower. Well-off individuals would repay more per year than affluent individuals, but repayment would stop for everyone when the full amount of the loan had been paid back with interest. This approach would considerably reduce the risk of adverse selection, but probably would not eliminate moral hazard. Unemployed and other non-working people would not have to repay, unless they secured unearned income, and those in very low income brackets might repay only part of the loan before retirement. But, of course, the longer the period of repayment, the more interest would be paid so that the poor would pay more interest than the wealthy.

If pure income-contingent loans replaced grants, the public budget would be reduced by the amount of the grants, except for two problems. First, the initial loans, before repayments started coming in, would probably be financed out of public money or at least be subsidized in order for the scheme to get off the ground. Second, even after the launching period, such a system would be bound to regularly bring about a deficit, whatever the solution chosen, as shown above.

In any case, a "forgiveness clause" that waives repayment of a loan, could be used by governments as an incentive to attract students to specific jobs that are in particular need of being filled (as an alternative method to bonding, that is financing students with the obligation to serve the government for a certain period after graduation). Other objectives can also be targeted through such a clause like rewarding academically outstanding students or encouraging rapid completion of degrees.

To sum up, there is a strong case to be made in favour of loans. When the local circumstances make them feasible, these loans should be of the income-related repayment type in order to provide mutual insurance. The amount to be repaid should not exceed-or at least not by muchthe amount borrowed plus the interest and service charges. More affluent graduates should repay more rapidly than their less successful colleagues, and an income threshold should be set under which repayment could be suspended.

Subsidization of the scheme by the public authorities, although inevitable, should be as small as possible in order not to distort the free choices of students. It should mainly consist of a public guarantee of the loans (which lowers the cost of borrowing by eliminating the risk component of the interest rate), rather than directly subsidizing the interest rate.

But a sudden switch from maintenance grants to loans is not acceptable. It would certainly meet with strong resistance from students or their unions and it would not be objectively satisfactory. It would affect equity negatively as the poorest would never be able to borrow enough to see themselves through long streams of study, and, more generally, it would discourage a growing number of students from enrolling, especially in long stream course programmes.

The conclusion is that a combination of guaranteed loans for all students and meanstested maintenance grants for the less affluent ones would be the optimal solution. In order to make students more responsible and to lessen the financial burden on the public budget, the extension of maintenance grants only to students who take a Joan of a minimum amount would be envisaged. 


\section{Summary}

To sum up, the optimal financial setting for higher education, which could be extended with some important qualifications to upper secondary education, seem to be the following:

Public Financing

- $\quad$ should be predominant;

- $\quad$ should consist of a mixture of:

- $\quad$ a basic unrestricted block grant to institutions ensuring a minimum of security and continuity;

- $\quad$ specific grants negotiated between each institution and one or several public bodies, phased over a period of several years, subject to interim evaluation and renegotiations;

- income related grants to students, helping to cover both tuition fees and maintenance;

- guarantees to student loans.

\section{Private Financing}

- $\quad$ in the shape of fees:

- $\quad$ basic tuition fees, uniforrn and substantial;

- $\quad$ additional specific fees for special services freely set up by institutions, within limits.

- business contributions:

- that should be limited, in the public and publicly subsidized sector, to the financing of continuing education and training, practical training included in the curriculum of regular degrees and applied research;

- that could be made compulsory in part through a payroll tax earmarked for education.

- $\quad$ gifts and endowments, that could be eased by changes in tax regulations but are likely to remain nominal in the short run for countries in which they are not rooted in traditions.

For most Western European countries and for other countries with a similar higher education funding system, this [solution] would mean :

- $\quad$ in most cases, a drastic rethinking of the relationship between public authorities and institutions;

- $\quad$ a progressive phasing out of the various subsidies for student services;

- $\quad$ the phasing out of tax relief for dependent students;

- $\quad$ substantial increases in tuition fees;

- $\quad$ the setting up of a guaranteed student loan system, and

- $\quad$ the increased participation of business.

Of course, each country will have to make its own choices according to its own constraints and political stances, but the logic of the present situation should lead them all to broadly similar choices. 


\section{REFERENCES}

BLAUG, M. An Introduction to the Economies of Education. Harmondsworth: Penguin, 1970.

COOMBS, P. The World Education Crisis: The Viewfrom the Eighties. New York: Oxford University Press, 1985.

GEIGER, R. L. Privatization of Higher Education: International Trends and Issues. New York : ICEO, 1988.

HUSEN, T. The School in Question. Oxford: University Press, 1979.

LESLIE, L. L., and BRINKMAN, P. T. The Economic Value of Higher Education. New York: American Council on Education and Macmillan, 1988.

MONK, D. H. Educational Finance. New York: MacGraw Hill, 1990.

PSACHAROPOULOS, G., and WOODHALL, M. Education for Development. New York: Oxford University Press, 1985.

WOODHALL, M. "Student Loans in Higher Education". DEP Dissemination Programme, Educational Forum, Series 1. Paris: IIEP, 1990. 